\title{
Purification, characterization and partial amino acid sequencing of two new aspartic proteinases from fresh flowers of Cynara cardunculus $\mathrm{L}$.
}

\author{
Paula VERÍSSIMO', Carlos FARO', Arthur J. G. MOIR ${ }^{2}$, Yingzhang LIN $^{3}$, Jordan TANG ${ }^{3}$ and Euclides PIRES \\ ' Departamento de Bioquímica, Faculdade de Ciências e Tecnologia, Universidade de Coimbra, Portugal \\ ${ }^{2}$ Department of Molecular Biology and Biotechnology, University of Sheffield, UK \\ ${ }^{3}$ Protein Studies Program, Oklahoma Medical Research Foundation and Department of Biochemistry and Molecular Biology, \\ University of Oklahoma Health Science Center, USA
}

(Received 31 October 1995) - EJB $951799 / 4$

\begin{abstract}
Two new aspartic proteinases have been isolated from stigmas of the cardoon Cynara cardunculus $\mathrm{L}$. by a two-step purification procedure including extraction at low $\mathrm{pH}$, gel filtration on Superdex 200 , and ion-exchange chromatography on Mono Q. To follow the conventional nomenclature for aspartic proteinases, we have named these proteinases cardosin $\mathrm{A}$ and cardosin B. On SDS/PAGE, cardosin A migrated as two bands with apparent molecular masses of $31000 \mathrm{Da}$ and $15000 \mathrm{Da}$ whercas the chains of cardosin $\mathrm{B}$ migrated as bands of $34000 \mathrm{Da}$ and $14000 \mathrm{Da}$. The partial amino acid sequences of the two cardosins revealed that they are similar but not identical, and that they differ from the previously reported cardoon proteinases named cynarases, which were assumed to be derived from a common precursor. Although the cardosins show some degree of similarity to each other, we could detect no immunological crossreactivity between them. Both cardosins were active at low $\mathrm{pH}$ and were inhibited by pepstatin, with $K_{\mathrm{i}}$ values of $3 \mathrm{nM}$ for cardosin $\mathrm{A}$ and $1 \mathrm{nM}$ for cardosin $\mathrm{B}$, indicaling that they belong to the class of aspartic proteinases. Significant differences between the two enzymes were also found for the $K_{\text {cis }} / k_{\mathrm{m}}$ values for the hydrolysis of two chromophoric synthetic peptides. The aclive-site ionization constants, $\mathrm{pK}_{+1}$ and $\mathrm{pK}_{\mathrm{c} 2}$, for cardosin $\mathrm{A}$ are $2.5 \pm 0.2$ and $5.3 \pm 0.2$, whereas for cardosin $B$ they are $3.73 \pm 0.09$ and $6.7 \pm 0.1$. The results herein described on the structural and kinetic properties of the cardosins indicate that they are the products of distinct genes which have probably arisen by gene duplication. A scheme for the proteolytic processing of the two enzymes is also proposed.
\end{abstract}

Keywords: Cynara cardanculus L.; aspartyl proteinases; milk-clotting enzymes; cardosins.

Aspartic proteinases are a group of enzymes that share many features in terms of sequence, three-dimensional structure and catalytic mechanism $[1-3]$. They are widely distributed in nature and have important roles in biological systems such as precursor protein processing (retroviral proteases), protein degradation (pepsin, cathepsin D and fungal proteases) and blood-pressure regulation (renin) (for reviews, see [3-51).

Only a small number of aspartic proteinases have been isolated and partially characterised from plants [6-13]. These proteinases, in common with most other aspartic proteinases, have an acid $\mathrm{pH}$ optimum, are inhibited by pepstatin and preferentially cleave peptide bonds between hydrophobic residues. Little is known about their biological functions, but it has been suggested that plant aspartic proteinases are involved in the hydrolysis of storage and intracellular protcins [14-17]. Recently, three aspartic proteinases from barlcy, rice and cardoon have been cloned and their amino acid sequences deduced [18-20]. A unique feature shared by all these enzymes is an extra scgment

Correspondence to C. I. C. Faro, Departamento Bioquimica, Universidade Coimbra, Apartado 3126, P-3000 Coimbra, Portugal

Abbreviations. Gdn/HCl, guanidine hydrochloride; $\mathrm{Phe}\left(\mathrm{NO}_{2}\right), p$-nitrophenylalanine; Ahx, 2-aminohexanoic acid; Tos- $\mathrm{PheCH}_{2} \mathrm{Cl}, \mathrm{L}-1-p-$ tosylamino-2-phenylethyl chloromethane.

Enzymes. Aspartic proteinases (EC 3.4.23); cathepsin D (EC 3.4.23.5); chymosin (EC 3.4.23.4); endoproteinase Glu-C (EC 3.4.21.19); pepsin (EC 3.4.23.1); renin (EC 3.4.23.15); trypsin (EC $3.4 .21 .4)$. of about 100 amino acids which bears no sequence similarity with aspartic proteinases of mammalian or microbial origins.

The flowers of cardoon (genus Cynara) are traditionally used in Portugal for cheese making and their proteinases are among the few enzymes from vegetal sources that have been used for this purpose. We have previously reported the isolation of a proteinase from commercially available dried cardoon flowers [21]. This two-chain enzyme was shown [22] to cleave k-casein at the same peptide bond (Phe105-Met106) as chymosin. A more recent study [23] reported the purification of three milk clotting enzymes from these flowers. These enzymes were named cynarases and were assumed to derive from a common precursor by different processing.

In the present work, two additional aspartic proteinases were isolated from fresh stigmas of a standard variety of Cynara cardunculus $\mathrm{L}$. grown from selected seeds. An investigation of the structural and kinetic properties of these enzymes indicates that they are the products of different genes and that they differ from the previously reported cynarases. To follow the descriptive nomenclature for other aspartic proteinases, we have named these new proteinases cardosin $A$ and cardosin $B$.

\section{MATERIALS AND METHODS}

Materials. Fresh flowers of C. cardunculus $\mathrm{L}$. were collected from plants grown from seeds supplied by the Botanical 
Gardens of the University of Coimbra. Pepstatin A was obtained from the Peptide Institute, Inc. Diazoacetyl-DL-norleucine methyl ester, trifluoromethanesulfonic acid and the peptide Leu-SerPhe $\left(\mathrm{NO}_{2}\right.$ )-Ahx-Ala-Leu-OMe (Ahx, 2-aminohexanoic acid; Phe $\left(\mathrm{NO}_{2}\right)$, p-nitrophenylalanine) were purchased from Sigma, USA. The peptide Lys-Pro-Ala-Glu-Phe-Phe $\left(\mathrm{NO}_{2}\right)$-Ala-Leu was synthesised at Krebs Institute, University of Sheffield, UK.

Enzyme assay. The proteolytic activity was assayed using the synthetic peptide Leu-Ser-Phe( $\mathrm{NO}_{2}$ )-Ahx-Ala-Leu-OMe as substrate [24]. Enzyme preparations were incubated at $37^{\circ} \mathrm{C}$ with $0.8 \mathrm{mM}$ substrate in $50 \mathrm{mM}$ sodium acetate, $\mathrm{pH} 4.7,0.2 \mathrm{M}$ $\mathrm{NaCl}, 4 \%(\mathrm{Me})_{2} \mathrm{SO}$, and the rate of hydrolysis of $\mathrm{Phe}\left(\mathrm{NO}_{2}\right)-\mathrm{Ahx}$ was monitored at $310 \mathrm{~nm}$ in a Perkin Elmer Lambda 2 UV/Vis spectrophotometer using the operating software. A molar absorption coefficient of $990 \mathrm{mM} / \mathrm{cm}$ at $310 \mathrm{~nm}$ was used in the calculations [24].

Protein determination. Protein concentration was determined by the method of Katzenellenbogen and Dobryszycka [25] using bovine serum albumin as standard.

Enzyme purification. Stigmas (1 g) from fresh flowers of C. cardunculus $\mathrm{L}$. were ground in a mortar and pestle under liquid nitrogen. The ground tissue was then homogenised in $5 \mathrm{ml}$

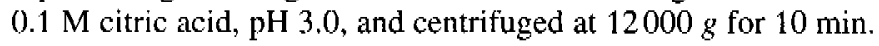
The supernatant $(4 \mathrm{ml})$ was applied to a HiLoad Superdex 200 column equilibrated and eluted with $25 \mathrm{mM}$ Tris/HCl, $\mathrm{pH} 7.6$ (buffer A), at a flow rate of $1.0 \mathrm{ml} / \mathrm{min}$. Each peak of absorbance was collected as a fraction and assayed for activity. The active fraction was applied to a Mono $Q$ HR $5 / 5$ column, also equilibrated in buffer $\mathrm{A}$. The protein was eluted with a linear gradient of $\mathrm{NaCl}(0-0.5 \mathrm{M})$ in buffer $A$ at a flow rate of $0.75 \mathrm{ml} / \mathrm{min}$ and the protein peaks were collected and assayed for activity.

Polyacrylamide gel electrophoresis. SDS/PAGE was performed in a BioRad Mini Protean II electrophoresis apparatus according to the method of Laemmli [26] or in a Pharmacia PhastSystem using $20 \%$ homogeneous gels as described in the manufacture manual.

Separation of the chains. Reverse-phase HPLC. Cardosins were reduccd and alkylated with 4-vinylpyridine, essentialy as described in [27]. The cardosins $(20 \mu \mathrm{g})$ were dissolved in $40 \mu \mathrm{l}$ alkylation buffer $[6 \mathrm{M}$ guanidine hydrochloride $(\mathrm{Gdn} / \mathrm{HCl})$, $0.5 \mathrm{M}$ Tris-Cl, $2 \mathrm{mM}$ EDTA, $\mathrm{pH} 7.5]$ and $1 \mu \mathrm{l} 1.4 \mathrm{M}$ dithiothreitol and incubated for $1 \mathrm{~h}$ at room temperature. To this mixture, $1 \mu \mathrm{l}$ 4-vinylpyridine was added and, after $5 \mathrm{~min}$, the reaction was stopped by the addition of $10 \mu \mathrm{l} 1.4 \mathrm{M}$ dithiothreitol. The S-pyridylcthylated enzyme was then separated into polypeptide chains by reverse-phase HPLC using a Vydac $\mathrm{C}_{4}$ column ( $4 \mathrm{~mm} \times 250 \mathrm{~mm}$ ) equilibrated in $20 \%$ acetonitrile in $0.1 \%$ (by vol.) $\mathrm{CF}_{3} \mathrm{CO}_{2} \mathrm{H}$. Elution was carricd out with a gradient of acetonitrile $(20-80 \%)$ containing $0.1 \%$ (by vol.) $\mathrm{CF}_{3} \mathrm{CO}_{2} \mathrm{H}$ in the eluent. The flow rate was $1.5 \mathrm{ml} / \mathrm{min}$ and the eluent was monitored continuously at $215 \mathrm{~nm}$.

Gel filtration in the presence of $6 \mathrm{M} \mathrm{Gdn} / \mathrm{HCl}$. A sample of cardosin $(0.5 \mathrm{ml})$ was dialysed against $0.1 \mathrm{M}$ sodium phosphatc, $\mathrm{pH} 6.5$, containing $6 \mathrm{M} \mathrm{Gdn} / \mathrm{HCl}$ and applied to a Pharmacia k16/100 column packed with Sephadex G-100 which had been equilibrated with the same buffer. The chains were eluted with the equilibration buffer at a low flow rate and the aborbance was monitored continuously at $280 \mathrm{~nm}$. The eluent containing the isolated chains was dialysed exhaustively against $0.05 \mathrm{M}$ $\mathrm{NH}_{4} \mathrm{HCO}_{3}$ and lyophilised.

CNBr and enzymic cleavage of cardosins. $\mathrm{CNBr}$ digestion/ $\mathrm{CNBr}$ cleavage was carried out in $70 \% \mathrm{CH}_{2} \mathrm{CO}_{2} \mathrm{H}(0.5 \mathrm{ml})$ and approximately $100 \mu \mathrm{g} \mathrm{CNBr}$. After $30 \mathrm{~min}$ at room temperature, the reaction mixture was lyophilised and redissolved in $8 \mathrm{M}$ urea, $2 \%$ SDS, $200 \mathrm{mM}$ Tris/bicine, $\mathrm{pH} 8.0$, and $2 \mathrm{mM} 2-\mathrm{mer}$ - captoethanol. The CNBr-cleaved peptides were then separated by SDS/PAGE followed by electroblotting onto poly(vinylidene difluoride) membranes.

Enzymic cleavage. The isolated chains of cach cardosin were incubated with $\mathrm{L}-1-p$-tosylamino-2-phenylcthylchloromethanetreated trypsin (4\%, by mass) in $25 \mathrm{mM}$ Tris/CI, pH 8.5, $0.3 \mathrm{M}$ $\mathrm{NaCl}$ for $20 \mathrm{~h}$ at $37^{\circ} \mathrm{C}$. The digests were then applied to an HPLC Vydac $C_{18}$ column $(4 \mathrm{~mm} \times 250 \mathrm{~mm}$ ) which was cquilibrated with $0.1 \% \mathrm{CF}_{3} \mathrm{CO}_{2} \mathrm{H}$, and the cardosin fragments eluted by a gradient of acetonitrile $(0-80 \%)$ in $0.1 \% \mathrm{CF}_{3} \mathrm{CO}_{2} \mathrm{H}$ at a flow rate of $0.5 \mathrm{ml} / \mathrm{min}$. The digestions of the isolated chains of cardosins $A$ and $B$ with endoproteinase $\mathrm{Glu}-\mathrm{C}$ ( $\mathrm{V}_{8}$ proteasc) were carried oul in $50 \mathrm{mM} \mathrm{NH} \mathrm{HCO}_{3}, \mathrm{pH} 8.1$, at $30^{\circ} \mathrm{C}$ for $10 \mathrm{~h}$ using an enzyme/substrate ratio of $1: 40$. The peptides produced were isolated by reverse-phase HPLC, as described above for tryptic peptides. Endoproteinase Gly-C digestion was performed in the same buffer (the enzyme/substrate ratio was $1: 50$ ) for $3 \mathrm{~h}$ at room temperature. The Gly-C peptides were separated by SDS/PAGE followed by electroblotting onto poly(vinylidene difluoride) membranes.

Sequence analysis. $N$-terminal amino acid sequences were determined by Edman degradation using an Applicd Biosystems 473-A Protein Sequencer equipped with a narrow bore HPLC for identification of the phenylthiohydantoin-amino acids.

Antibody production and Western-blot analysis. The isolated 31-kDa chain of cardosin A $(0.5 \mathrm{mg})$ was cmulsificd with Freund's complete adjuvant and injected subcutaneously into New 7ealand rabbits. A second injection was made 2 weeks later using the same amount of isolated chain emulsified with Frcund's incomplete adjuvant, and antiserum was prepared from blood taken 1 week after this last injection.

For Western-blot analysis, the cardosin chains were separated by SDS/PAGE on a $12 \%$ polyacrylamide gel and transferred to a poly(vinylidene difluoride) membrane by electrobloting in 10 $\mathrm{mM}$ 3-cyclohexylamino-1-propanesulfonic acid, $10 \%$ methanol, $\mathrm{pH} 11.0$, at $500 \mathrm{~mA}$ for $1 \mathrm{~h}$. The membrane was incubated in a blocking solution $(2.5 \%$ skimmed milk in $0.1 \mathrm{M}$ $\mathrm{NaCl} / 0.1 \mathrm{M}$ sodium phosphate, $\mathrm{pH} 7.5 /$ Tween) for $45 \mathrm{~min}$ at room tempcrature, then incubated overnight with an 1:500 dilution of the rabbit serum against the $31-\mathrm{kDa}$ chain. The membranc was washed three times with $80 \mathrm{mM} \mathrm{Na} \mathrm{HPO}_{4}, 20 \mathrm{mM}$ $\mathrm{NaH}_{2} \mathrm{PO}_{4}, 100 \mathrm{mM} \mathrm{NaCl}$, pH $7.5\left(\mathrm{NaCl} / \mathrm{P}_{i}\right), 0.1 \%$ Tween for 10 min and incubated with goat anti-rabbit $\operatorname{IgG}$ conjugated to horseradish peroxidase at a 1:500 dilution for $1 \mathrm{~h}$. After washing the membrane three times with $\mathrm{NaCl} / \mathrm{P} /$ /Tween for $10 \mathrm{~min}$, the peroxidase aclivity was developed with $3,3^{\prime}$-diaminobenzidine $\left(0.01 \%\right.$ in $\mathrm{NaCl} / \mathrm{P}_{\mathrm{i}} /$ Tween $)$ in the presence of $0.1 \% \mathrm{H}_{2} \mathrm{O}_{2}$.

Kinetics studies. For kinetics studies, the expcrimental conditions were those above described for the encyme assay cxcept that the rate of hydrolysis for substrates was monitored in a HP 8452A diode array spectrophotometer using the HP89531A UV/ VIS operating software. A molar absorption coefficient of $1480 \mathrm{mM} / \mathrm{cm}$ at $300 \mathrm{~nm}$ was used in the calculations when the synthetic peptide Lys-Pro-Ala-Glu-Phe-Phe $\left(\mathrm{NO}_{2}\right)$-Ala-Leu was used as substrate. The enzyme concentration was determined by active-site titration of cardosins $\mathrm{A}$ and $\mathrm{B}$ with pepstatin $\mathrm{A}$. For the kinetic studies at different pHs, the buffers were $50 \mathrm{mM}$ $\mathrm{CH}_{2} \mathrm{ClCO}_{2} \mathrm{Na}(\mathrm{pH}<3.5), 50 \mathrm{mM} \mathrm{CH} 2 \mathrm{CO}_{2} \mathrm{Na}(\mathrm{pH} 3.5-5.5)$ and $50 \mathrm{mM}$ Bis/Tris/Cl ( $\mathrm{pH}>5.5)$. The hydrolysis of the peptide bonds Phc $\left(\mathrm{NO}_{2}\right)$-Ahx and Phe-Phe $\left(\mathrm{NO}_{2}\right)$ was confirmed by reverse-phase HPLC. The kinetics parameters were calculated from the I.ineweaver-Burk plot using an approprialed software. The inhibition constant for pepstatin was calculated according to Green and Work [28]. 


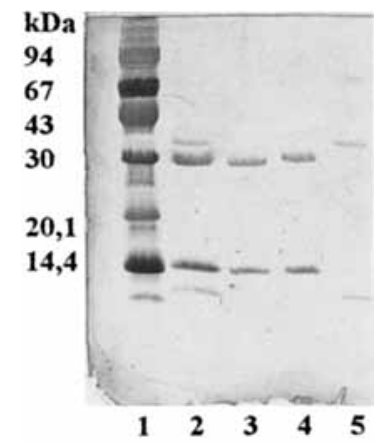

Fig. 1. SDS/PAGE on a Phastgel homogeneous 20 of the enzyme preparation at each step of the purification of cardosins. The gel was stained with Coomassie brilliant blue. Lane 1, extract of cardoon stigmas; lane 2, first (inactive) peak from chromatography on a Mono $Q$ column (Fig. 2B); lane 3, purified cardosin A (from the second peak, Fig. 2B); lane 4, purified cardosin B (from the third peak, Fig. 2B)

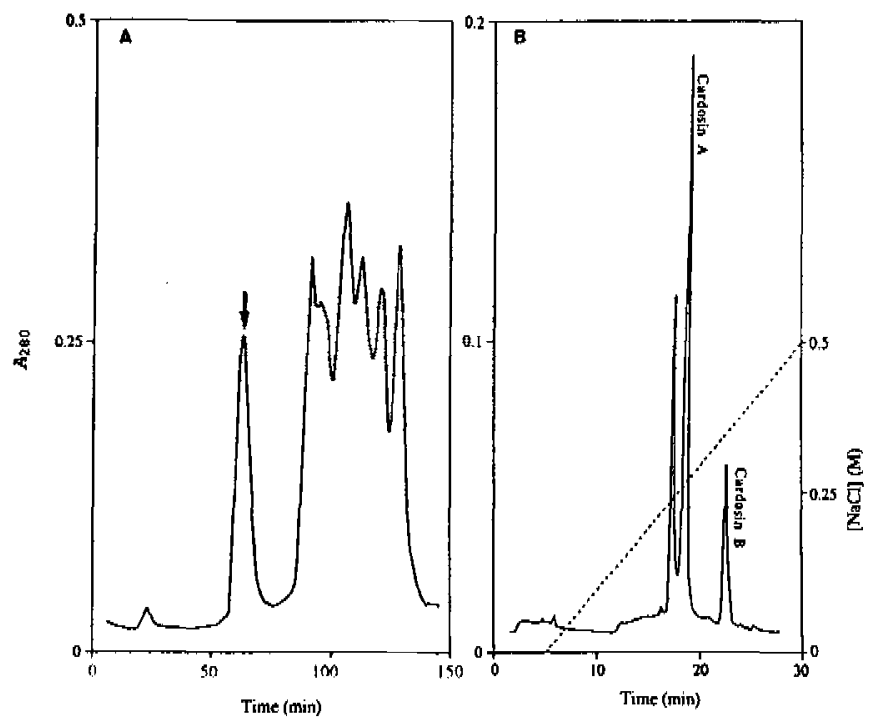

Fig. 2. Purification of cardosins A and B. (A) Gel filtration on Superdex 200 of the acidic extract of $C$ cardunculus $L$. Samples $(4 \mathrm{ml})$ of an acidic extract of fresh stigmas of $C$. cardunculus $L$. were applied to a HiLoad Superdex 200 column equilibrated with $25 \mathrm{mM}$ Tris/Cl, $\mathrm{pH} 7.6$. The column was eluted with the same buffer at a flow rate of $1 \mathrm{ml} / \mathrm{min}$. The protease activity is associated with the peak indicated by an arrow. (B) Chromatography on Mono $Q$ of the active fraction isolated from Superdex 200. The active fraction from Superdex 200 was applied to a HR 5/5 Mono Q column equilibrated with $25 \mathrm{mM}$ Tris/Cl, $\mathrm{pH} 7.6$. The column was cluted with a linear gradient of $0.5 \mathrm{M} \mathrm{NaCl}$ in the equilibration buffer at a flow rate of $0.75 \mathrm{ml} / \mathrm{min}$.

\section{RESULTS}

Purification of cardosins. The milk curdling enzyme preparation from the flowers of cardoon is traditionally obtained by water extraction or by grinding dried flowers with coarse salt into a fine powder. As water extraction yields an enzyme preparation with a $\mathrm{pH}$ of about 5.5 , this $\mathrm{pH}$ was initially used to extract cardosins from fresh flowers of cardoon. However, extraction at $\mathrm{pH} 3.0$ was found to yield an extract with higher activity than that obtained at $\mathrm{pH} 7.6$ or $\mathrm{pH} 5.5$. In addition, extraction at low $\mathrm{pH}$ eliminated most protein contaminants, as judged by SDS/PAGE analysis where only the bands from cardosins were observed (Fig. 1, lane 2). Extraction at low $\mathrm{pH}$ was followed by gel filtration on Superdex 200 (Fig. 2A). The proteolytic activity was recovered from this column as a single peak with an yield
Table 1. Summary of the purification procedure of cardosin $A$ and cardosin B from fresh stigmas of C. cardunculus $L$.

\begin{tabular}{lllll}
\hline Step & Protein & $\begin{array}{l}\text { Specific } \\
\text { activity }\end{array}$ & $\begin{array}{l}\text { Total } \\
\text { activity }\end{array}$ & Yield \\
\hline & $\mathrm{mg}$ & Units/mg & Units & $\%$ \\
Acidid extract & 7.33 & 16.31 & 119.5 & 100 \\
$\begin{array}{l}\text { Superdex 200 } \\
\text { Mono Q }\end{array}$ & 4.14 & 20.88 & 86.36 & 72.3 \\
cardosin A & 2.15 & 7.96 & 17.12 & 60.2 \\
cardosin B & 0.6 & 91.8 & 54.76 & \\
\hline
\end{tabular}

of about $72 \%$. Peaks eluted after the active fraction were found to contain non-protein material, as no electrophoretic band was observed on SDS/PAGE. This material had a yellow color and tended to be retarded on the column. The partially purified preparation obtained upon gel filtration was finally fractionated into three peaks by jon-exchange chromatography on Mono $Q$ (Fig. 2 B). The first component eluted at 17 min had no proteolytic activity towards the synthetic peptide used as substrate. The second and third peaks contained active enzymes which werc named cardosin $A$ and cardosin B. SDS/PAGE of these two proteinases revealed that each produced two bands either in the presence or in the absence of 2-mercaptoethanol with apparent molecular masses of $31 \mathrm{kDa}$ and $15 \mathrm{kDa}$, respectively, for cardosin $\mathrm{A}$ and $34 \mathrm{kDa}$ and $14 \mathrm{kDa}$, respectively, for cardosin $\mathrm{B}$ (Fig. 1). The inative component recovered from the Mono $Q$ column also gave two bands on SDS/PAGE corresponding to apparent molecular masses of $31 \mathrm{kDa}$ and $15 \mathrm{kDa}$ (Table 1 ; Fig. 1).

Comparison of cardosins. $N$-terminal amino acid sequencing. The relationship between cardosins was first investigated by determining the $\mathrm{N}$-terminal amino acid sequence of each chain after separation by SDS/PAGE and electrotransference to poly(vinylidene difluoride) membranes (Fig. 3). The sequences of the two chains from cardosin A are different, but homologous, to thosc obtained for the corresponding chains from cardosin B, demonstrating that the two cardosins are products of different genes. In contrast, the N-tcrminal sequences of the $31 \mathrm{kDa}$ and $15-\mathrm{kD}$ a chains of cardosin $\mathrm{A}$ are identical to those obtained for the chains recovered from the material identified as peak 1 in Fig. $2 \mathrm{~B}$, further confirming that this material is related to cardosin A.

Internal amino acid sequencing. In order to obtain internal amino acid scquence data, the polypetide chains of both cardosins were isolated by reverse-phase HPLC or by gel filtration in the presence of $6 \mathrm{M} \mathrm{Gdn} / \mathrm{HCl}$. Reverse-phase chromatography on a $\mathrm{C}_{4}$ column of the alkylated cardosin $\mathrm{A}$ yielded two peaks (Fig. 4A) which were confirmed to be the $15-\mathrm{kDa}$ and $31-\mathrm{kDa}$ chains by SDS/PAGE. Using the same separation method, cardosin $B$ was also fractionated into two peaks, which were identified by SDS/PAGE as the 14-kDa and 34-kDa chains, respectively. The elution times of the cardosin $B$ chains were different from those of the equivalent chains of cardosin A. Altematively, the chains of each cardosin were isolated by gel filtration on Sephadex G-100 in the presence of $6 \mathrm{M}$ Gdn/HCl. In contrast, the chains could not be separated by gel filtration in the presence of $6 \mathrm{M}$ urea (results not shown), suggesting that a strong interaction cxists between the two chains of each cardosin.

The isolated chains were then digested with CNBr, trypsin and $V 8$ protease and the peptide fragments were subsequently separated by reverse-phase HPLC on a $\mathrm{C}_{18}$ column or by SDS/ PAGE followed by electrotransference to a poly(vinylidene difluoride) membrane for automated Edman degradation. By this 
CYP 1 RDSDGELIAL KNYMDAOYFG EILIG-TPRQ KFTVIFOIGS SNIWVSSKC

CA(30kD) $\star * G S A V V * * T * \mathrm{DR}^{\star} \mathrm{TD}^{\star \star \star * * * \mathrm{PTO}}$

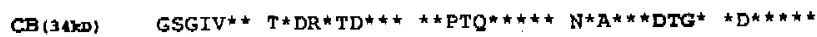

CYP 51 YFSVACLFHS KYRSTDSTTY KKNGKSAAIQ YGTGSISGFF SQDSVKLGDL

CA $\star \star S^{\star \star} \mathrm{S}^{\star \star} *$ * SF*TK*

CYP 101 LEVKEODEIE ATKEPGITFL AAKFDGILGL GFQEISVGDA VPVWYTMLNO CA $\quad * * * * * * * D^{*} T$ TDNV** CE $\quad * * * \mathrm{~A}^{*} \mathrm{~K}^{*} * \hbar * * \mathrm{MMV}^{*}$

CYP 131 GLVQEPVFSF WLNRNADEQE GGELVFGGVD PNHFKGEHTY VEVTQGYWOE

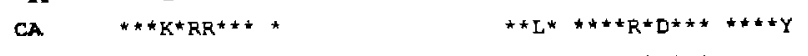

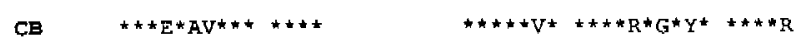

CYP 201 EMGDVLIGDK TTGFCASGCA AIADSGTSLL AGTTTIVTOI NQAIGAAGV

CA

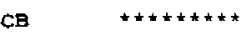

CYP 231 MSOOCKSL----.----349 PSPMGESAVD CSSLSSMPNI AFTVGGKTEN CA (15kD) $T S S E * L Q * * N T * R^{*} * N V S \underline{S}^{* *} I * * K * G$

CB (14kD) $S A * S I * * N G I * S * * N T A * \pm * \star * K$

CYP 379 LSPEQYVLKV GEGATAOCIS GFTAMDVAPP HGPLWILGDV FMGQYHTVFD CA $\quad * T * * \$ Y$

$\mathrm{CB} \quad * \mathrm{~T} * *$

GP 429 YGNLRVGFAE AA

CA

$\mathrm{CB} \quad * * \mathrm{~KB}^{* \star \star \star * *}$

Fig. 3. Alignment of the partial amino acid sequences of cardosins $A$ (CA) and $B$ (CB) with that derived from the sequence of a partial cDNA of cynarase [20]. The partial sequence of each cardosin was determined upon sequencing of several peptides originated from digestions of the isolated subunits with CNBr, trypsin, endo-Gly and endoGlu as described in Materials and Methods. Identical residues are indicated by ${ }^{*}$. The active-site triads DTG and DSG are show in bold. The $N$-glycosylated site of the $15-\mathrm{kDa}$ chain is underlined.

method, the partial amino acid sequences of the chains of both cardosins were determined (Fig. 3), revealing a clear similarity between the sequences of the cardosins $\mathrm{A}$ and $\mathrm{B}$ chains. A further similarity is also apparent between the cardosins and the previously reported partial cDNA sequence of a cynarase (Fig. 3).

Immunoblotting analysis. In order to further investigate the relationship between the isolated cardosins, the purified $31-\mathrm{kDa}$ chain of cardosin A was used to raise a rabbit antiserum. Immunoblotting analysis showed that cardosin B did not crossreact with this antiserum (Fig. 5), indicating that there is no immunoidentity between the two cnzymes. As expected, the $31-\mathrm{kDa}$ chain of the material from the first peak on Mono $Q$ also reacts with the antiserum (Fig. 5), suggesting, therefore, that this protein is closely related to cardosin A.

Enzymic properties and kinetic studies. Cardosins are active at $\mathrm{pH} 2-7$ with maximal activities around $\mathrm{pH} 5.0$. Both enzymes are stable at temperatures up to $60^{\circ} \mathrm{C}$. In dilute solutions, the cardosins tend to be adsorbed onto solid surfaces, so they can be transferred quantitatively only in the presence of a carrier protein such as serum albumin or $\mathrm{k}$-casein. Both enzymes were inhibited by the specific aspartic proteinase inhibitors, diazoacetyl-norleucine methyl ester and pepstatin. Inhibition constants determined in the presence of pepstatin are $3 \mathrm{nM}$ for cardosin $\mathrm{A}$ and $1 \mathrm{nM}$ for cardosin B (Fig. 6; Table 2). The $\mathrm{pH}$ dependence of the kinetic parameters $K_{\mathrm{n}}, k_{\text {cut }}$ and $k_{\mathrm{car}} / K_{\mathrm{m}}$ for cardosins was investigated using the peptide substrate Lys-Pro-Ala-

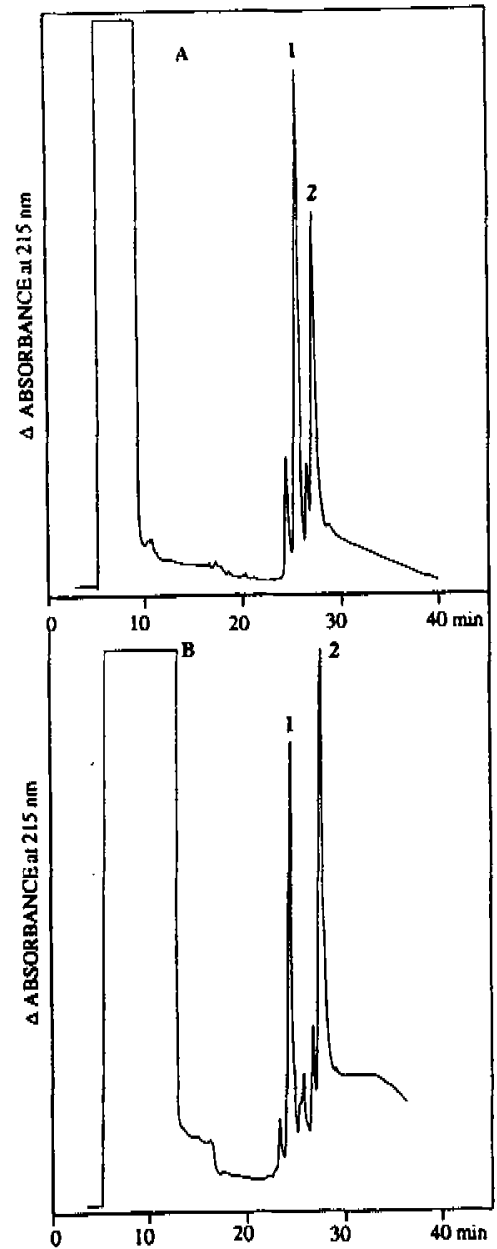

Fig. 4. Separation of the constituent polypeptide chains of cardosin $A$ and cardosin $B$ by reverse-phase-HPLC. The reduced and alkylated cardosin $\mathrm{A}$ was applied to a Vydac $\mathrm{C}_{4}$ column equilibrated with $20 \%$ acetonitrile in $0.1 \% \mathrm{CF}_{3} \mathrm{CO}_{2} \mathrm{H}$. The chains were eluted with a linear gradient of acetonitrile $(20-80 \%$ in $40 \mathrm{~min}$ ) at a flow rate of $1.5 \mathrm{ml} /$ min. (A) Peak 1, 15-kDa chain; peak 2, 31-kDa chain. Purificd cardosin $B$ was scparated into its subunits by reverse-phase HPLC using the same conditions as described above. (B) Peak 1, 14-kDa chain; peak 2, 34kDa chain.

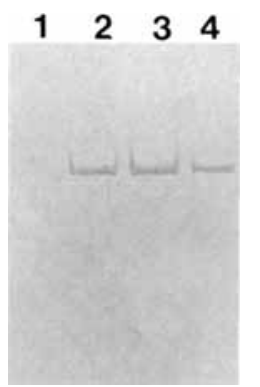

Fig. 5. Immumoblotting analysis of the relationship between cardosin A and cardosin B. The isolated enzymes were subjected to SDS/PAGE on a $12.5 \%$ polyacrylamide gel and transferred by electrobloting onto poly(vinylidene difluoride) membranes. An antiscrum raised against the isolated $31-\mathrm{kDa}$ chain of cardosin $\mathrm{A}$ was used as a probe. The antigenicantibody complex was developed with a horseradish-peroxidase-conjugated goat anti-rabbit serum using 3,3'-diaminobenzidine as chromogenic substrate. Lane 1, cardosin B; lane 2, cardosin A; lane 3, inactive cardosin; lane 4, acid extract. 


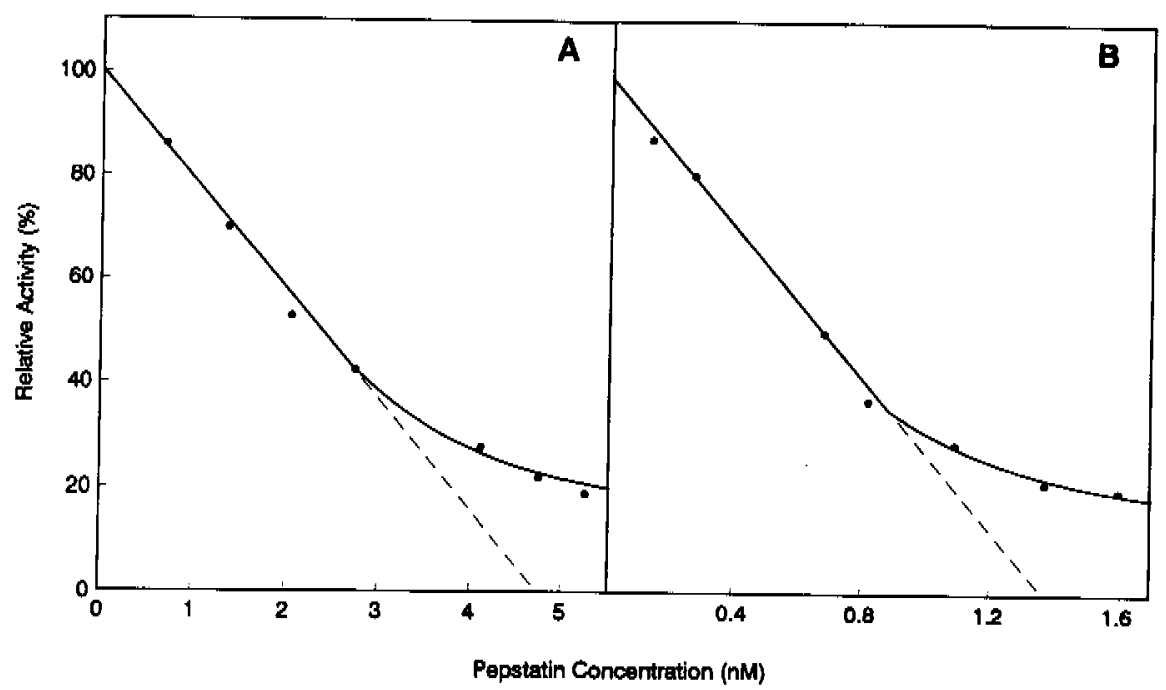

Fig. 6. Inhibition of cardosin $\mathbf{A}(\mathbf{A})$ and cardosin $\mathbf{B}$ (B) by pepstatin $\mathrm{A}$. The assays were carried out in $0.1 \mathrm{M}$ sodium acetatc, $\mathrm{pH} 4.7$, using the synthetic peptide Lys-Pro-Ala-Glu-Phe-Phe $\left(\mathrm{NO}_{2}\right)$-Ala-Leu as substrate. The inhibition constant was calculated according to the method of Green and Work [28].

Table 2. Kinetic constants for the hydrolysis of two synthetic peptides by cardosin A and B.

\begin{tabular}{|c|c|c|c|c|c|c|}
\hline \multirow[t]{2}{*}{ Enzyme } & \multicolumn{3}{|c|}{ Leu-Ser-Phc(NO} & \multicolumn{3}{|c|}{ Lys-Pro-Ala-Glu-Phe-Phe( $\left.\mathrm{NO}_{2}\right)$-Ala-Leu } \\
\hline & $K_{\mathrm{m}}$ & $k_{\text {c:itr }}$ & $k_{\mathrm{cus}} / K_{\mathrm{m}}$ & $K_{\mathrm{m}}$ & $k_{\text {:atrt }}$ & $k_{\text {cit }} / K_{\mathrm{m}}$ \\
\hline Cardosin A & $0.64 \pm 0.02$ & $13.7 \pm 1.6$ & $21.3 \pm 1.27$ & $0.108 \pm 0.086$ & $55.63 \pm 6.12$ & $515.09 \pm 56.7$ \\
\hline Cardosin B & $0.081 \pm 0.01$ & $86.2 \pm 10.3$ & $1065.7 \pm 53.4$ & $0.11 \pm 0.012$ & $89.4 \pm 3.5$ & $808.3 \pm 32.3$ \\
\hline
\end{tabular}

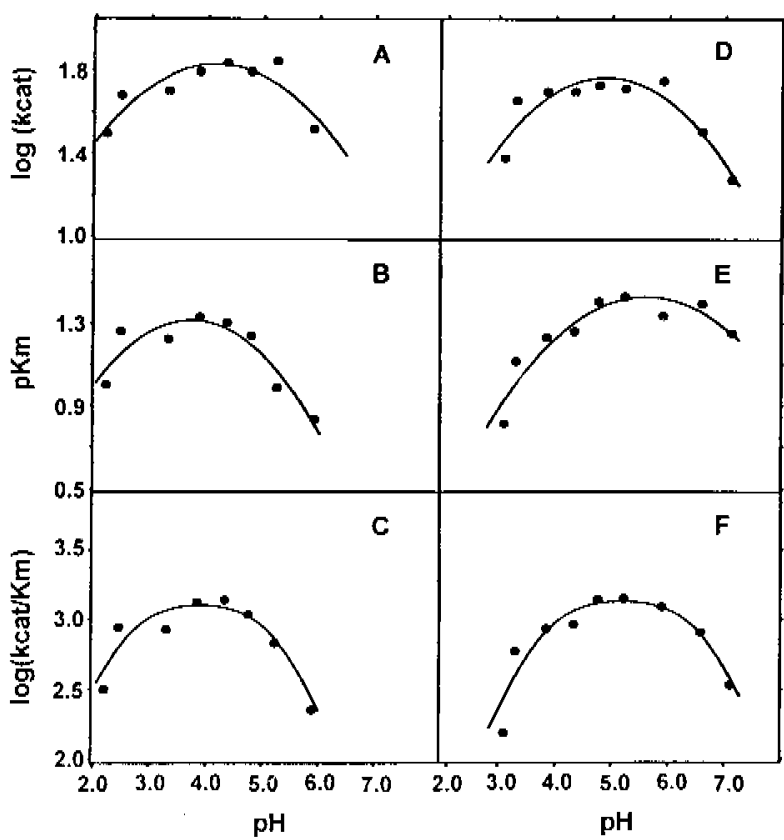

Fig. 7. pH dependence of the kinetic parameters of cardosin $\Lambda(a-c)$ and cardosin $B(d-1)$. The kinetic parameters were determined as described in Materials and Methods. The synthetic peptide Leu-SerPhe $\left(\mathrm{NO}_{2}\right)$-Ahx-Ala-Leu-OMe was used for cardosin A and Lys-Pro-AlaGlu-Phe-Phe $\left(\mathrm{NO}_{2}\right)$-Ala-Leu was used for cardosin $\mathrm{B}$. The buffers were $50 \mathrm{mM} \mathrm{CH}_{2} \mathrm{ClCO}_{2} \mathrm{Na}(\mathrm{pH}<3.5), 50 \mathrm{mM} \mathrm{CH} \mathrm{CO}_{2} \mathrm{Na}(\mathrm{pH} 3.5-5.5)$ and $50 \mathrm{mM} \mathrm{Bis} / \mathrm{Tris} / \mathrm{Cl}(\mathrm{pH}>5.5)$.
Glu-Phe-Phc-Phe $\left(\mathrm{NO}_{2}\right)$-Ala-Leu for cardosin A (Fig. 7, A-C) and the peptide Len-Ser-Phe( $\mathrm{NO}_{2}$-Ahx-Ala-Leu-OMe for cardosin B (Fig. 7, D-F). The pH-dependence curves are bell shaped and the values determined for the apparent active-site ionization constants $\mathrm{pK}_{\mathrm{e} 1}$ and $\mathrm{pK}_{\mathrm{c} 2}$ of the free enzyme are respectively $2.5 \pm 0.2$ and $5.3 \pm 0.2$ for cardosin $A$ and $3.73 \pm 0.09$ and $6.7 \pm 0.1$ for cardosin $B$.

\section{DISCUSSION}

The flower of cardoon is a rich source of aspartic proteinases. Indeed, these enzymes account for morc than $60 \%$ of the total protein in mature stigmas and, to the best of our knowledge, they seem to be the first example of highly abundant aspartic proteinases in higher plants. Previous studies from this and other laboratories have described the isolation of aspartic proteinases from dried flowers of cardoon [21, 23]. In the present work, we describe the isolation of two new aspartic proteinases from fresh stigmas of $C$. cardunculus $\mathrm{L}$. using a simple procedure in which the proteinases are first extracted from stigmas at low $\mathrm{pH}$, then purified by gel filtration using Superdex 200 followed by ion-exchange chromatography using Mono Q, the entire purification being achieved in just $2 \mathrm{~h}$. The simplicily in this isolation procedure compares favourably with that for the isolation of the cynarases [23]. In the present procedure, fresh flowers were used as starting material, which should be a better source of the enzymes because it avoids the chemical modification occurred during the drying process. We have observed that the specificity and kinetic properties of the enzymes isolated from dried flowers are different from those isolated from fresh 
Cardosin A

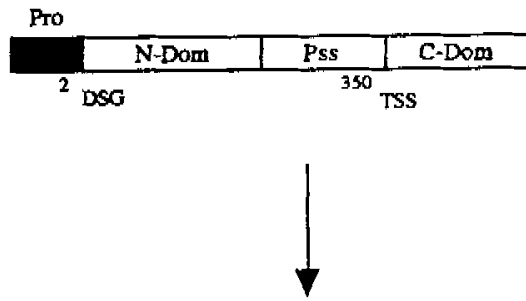

Precursor form

$31 \mathrm{kDa}$

$15 \mathrm{kDa}$

Cardosin B
Precursor form
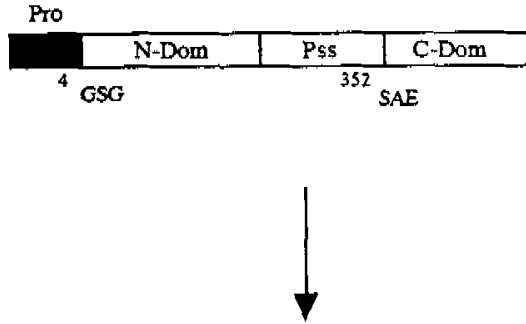

$34 \mathrm{kD}$

mature caróosin B

Fig. 8. Schematic representation of the proteolytic processing of cardosins. The two cardosins are likely to be produced as single chains which undergo proteolytic processing at the N-terminus by removal of the prosequence. The two precursors are further activaled by removal of an internal sequence which is known as the plant-aspartic-proteinase-specific sequence. This sequence bears no similarity to the mammalian and microbial aspartic proteinases. Pro, prosegment; N-Dom, N-terninal domain; Pss, plant-aspartic-proteinases-specific sequence; C-I)om, C-terminal domain; Gl, $N$-glycosylated site.

flowers (unpublished results), suggesting that the catalytic properties of these enzymes are modified during the drying process. The usc of fresh flowers as the starting material has revealed, furthermore, that the elution profile obtained by chromatography on Mono $Q$ is dependent on the type of cardoon, which has allowed us to perform a screening on the proteinase composition of different species of Cynara [29].

The partial amino acid sequence data (Fig. 3) indicate that the two cardosins are the products of different genes. Although they show some degree of similarity, we cannot detect any immunological cross-reactivity between them. Furthermore, there are significant differences between the enzymic and kinetic properties of the cardosins. The partial sequence data (Fig. 3) also reveals that the cardosins are distinct gene products from the cynarases. In addition, the latter proteinases are assumed to be derived from a single precursor by different proteolytic processing [23], whereas cardosins are clearly encoded by two distinct genes.

Evidence presented in this paper clearly shows that the cardosins belong unequivocally to the family of aspartic proteinases. The isolated cardosins are inhibited by the general aspartic proteinase inhibitors, pepstatin and diazoacetyl-DL-norleucine methyl ester, and are active at acid $\mathrm{pH}$. Like the majority of the other aspartic proteinases, cardosins preferentially cleave peptide bonds between residues with hydrophobic side chains. Using oxidised insulin B chain as substrate, we have previously shown that cardosin $B$ has a broader specificity than cardosin $A$ [30]. Clear differences were also found between the two cnzymes concerning the kinetic values for the hydrolysis of the synthetic peptide Leu-Ser-Phe $\left(\mathrm{NO}_{2}\right)$-Ahx-Ala-Leu-oMc. The $k_{\mathrm{cit}} / K_{\mathrm{m}}$ value determined for cardosin $\mathrm{B}$ is in the same range as that of pepsin $\left(1640 \mathrm{mM}^{-1} \mathrm{~s}^{1}\right)$ whereas the value for cardosin
A is similar to that for chymosin $\left(25.6 \mathrm{mM}^{-1} \mathrm{~s}^{1}\right)$. Although the precise specificities of the cardosins will requirc the study of more substrates, the results nevertheless suggest that the general specificity of cardosin $A$ is similar to that of chymosin, whereas that of cardosin B closely resembles the specificity of pepsin [30]. Cardosins have also different active-site ionization constants, although the $\mathrm{pK}$ values for the free enzymes fall within the range of the active-site ionization constants determined for other aspartic proteinases. However, it is noteworthy to mention that the values for both cardosins are closer to those of the human immunodeficiency virus type 1 protease [31] than of pepsin and rhizopuspepsin [32]. This may be duc to the fact that, like retroviral proteinases, cardosins have optimal activity under mild acid conditions. Among the known plant aspartic proteinases, cardosins appear to have a $\mathrm{pH}$ optimum somewhat higher than that of the other enzymes. In general, the $\mathrm{pH}$ optimum of plant aspartic proteinases ranges over $2-2.5$ for those enzymes

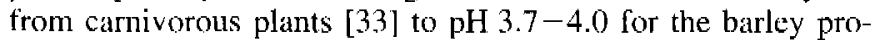
teinase 161. The $\mathrm{pH}$ optimum of cardosins may reflect their subcellular localization. Like the barlcy proteinase $\$ 34]$ and the most closely related aspartic protcinases from animals [35] and yeast [36], cardosins are likely to be vacuolar enzymes. However, they are probably involved in different proteolytic events, and while cardosin B may take part in general protcin digestion, cardosin A may have a function in a more specific regulated process.

Nearly all of the aspartic proteinases are synthesised as single-chain zymogens and activated upon removal of the propeptide [1]. Aspartic proteinases such as cathepsin D and the barley proteinase, however, undergo further proteolytic processing from single-chain to two-chain enzymes. It is possible that the activation of cardosins also takes place during the biosynthesis and 
intracellular processing of the enzymes. The sequence data presented here suggest that processing of the single-chain cardosin to produce the two-chain enzyme is likely to occur through the cleavage of two peptide bonds, resulting in the removal of the region whose sequence is specific for plant aspartic proteinases (Fig. 8). This is suggested by sequence alignment of the cardosins to the barley proteinase and the cynarase, as well as by the amino acid composition of each chain. The three-dimensional structures of a large number of aspartic proteinases are known [2], and recently a three-dimensional model for the barley proteinase was proposed. According to this model, the specific insert is present at the $\mathrm{C}$-domain neat the surface between residues G239 and G243 [37]. This sequence is located in a position that would probably generate a second loop over the active site, resulting in a hindrance to the access of substrate, and thus should be removed in order to render a fully active enzyme. The existence of an inactive form containing the plant-specific insert may therefore be an interesting stratcgy to overcome unwanted protcolysis in the cell and the search for such form in cardosins is currently under investigation in our laboratory.

This work was mainly supported by JNICT, Portugal (contract number PMCT/C/BIO/909/90). Paula Veríssimo is the recipient of a PhD fellowship from Junta Nacional de Investigaçāo Cientifica e Tecnológica (JNICT), Portugal.

\section{REFERENCES}

1. Tang, J. \& Wong, R. N. S. (1987) Evolution in the structure and function of aspartic proteinases, $J$. Cell Biochem. 33, 53-63.

2. Davies, D. R. (1990) The structure and function of the aspartic proteinases, Annu. Rev. Biophys. Chem. 19, 189-215.

3. Dunn, B. M. (1992) Stracture and function of the aspartic proteinases (Dunn, B., ed.) Plenum Press, New York.

4. Tang, J. (1977) Acid proteases, structure, function and biology (Tang, J., ed, Plenum Press, New York.

5. Kostka, V. (1985) Aspartic proteinases and their inhibilors (Kostka, V., ed.) Walter de Gruyter, Berlin.

6. Sarkkinen, P., Kalkkinen, N., Tilgmann, C., Siuro, J., Kervinen, J. \& Mikkola, L. (1992) Aspartic proteinase from barley grains is related to mammalian lysosomal cathepsin D. Planta (Berlin) 186 , $317-323$.

7. Belozersky, M. A., Sarbakanova, S. T. \& Dunaevsky, Y. E. (1989) Aspartic proteinase from wheat sceds: isolation, properties and action on gliadin, Planta (Berlin) 177, 321-326.

8. Doi, E., Shibata, D., Matoba, T. \& Yonezawa, D. (1980) Characterization of pepstatin-sensitive acid protease in resting rice seeds, Agric. Biol. Chem. 44, 741-747.

9. Polanowski, A., Wilusz, T., Kolaczkowska, M. K., Wieczorek, M. \& Wilinowska-Pelc, A. (1985) Purification and characterization of aspartic proteinases from Cucumis sativus and Curcubita maxima seeds, in Aspartic proteinases and their inhibitors (Kostka, V., ed.) pp. 49-52, Walter de Gruyter, New York.

10. Garg, G. K. \& Virupaksha, T. K. (1970) Acid Proteasc from germinated sorghum: 1-purification and characterization of the enzyme, Eur: J. Biochem. 17, 4-12.

11. Rodrigo, I., Vera, P. \& Conejero, V. (1989) Degradation of tomato pathogenesis-related proteins by an endogenous $37-\mathrm{kDa}$ aspartyl endoproteinase, Eur. J. Biochem, 184, 663-669.

12. Bourgeois, J \& Malek, L. (1991) Purification and characterization of the aspartyl proteinase from dry jack pine seeds, Seed Sci. Res. $1,139-147$

13. Salmia, M. A. (1981) Proteinases activities in resting and germinating seeds of Scots pine, Pinus sylvestris, Physiol. Plant. 53, 39-47.

14. Juniper, B. E., Robins, R. J. \& Joel, D. M. (1989) The Carnivorous plants (Juniper, B. E., Robins, R. J. \& Joel, D. M., eds) pp. $189-$ 207, Academic Press Inc., London.

15. D'Hondt, K., Bosch, D., Van Damme, J., Goethals, M., Vandekerckhove, J. \& Krebbers, E. (1993) An aspartic proteinasc present in seeds clcaves Arabidopsis $2 \mathrm{~S}$ albumin precursors in vitro, $J$. Biol. Chem. 268, 20884-20891.
16. Elpidina, E. N., Dunaevsky, Y. E. \& Belozersky, M. A. (1990) Protein bodies from buckwheat seed cotyledons: isolation and characterization, J. Exp. Bot. 41, 969-977.

17. Rodrigo, I., Vera, P. \& Van Loon, L. C. (1991) Degradation of tobacco pathogenesis-related proteins, Plant Physiol. 95, 616-622.

18. Runeberg-Roos, P., Tormakangas, K. \& Ostman, A. (1991) Primary structure of a barley-grain aspartic proteinase. A plant aspartic proteinase rescmbling marnmalian cathepsin D, Eur. J. Biochem. 202, 1021-1027.

19. Asakura, T., Watanabe, H., Abe, K. \& Arai, S. (1995) Rice aspartic proleinase, oryzasin, expressed during seed ripening and germination, has a gene organization distinct from those of anitmal and microbial aspartic proteinases, Eur. J. Biochem. 232, 77-83.

20. Cotdeiro, M. C., Xue, Z.-T., Pietrzak, M., Pais, M. S. \& Brodelius, P. E. (1994) lsolation and characterization of a cDNA from flow. ers of Cynara cardunculus encoding cyprosin (an aspartic proteinase) and its use to study the organ-specilic expression of cyprosin, Plant Mol. Biol. 24, 733-741.

21. Faro, C., Alface, J. S. \& Pires, E. V. (1987) Purification of a protease from the flowers of Cynara cardunculus L., Ciênc. Biol. 12, 5A 201.

22. Faro, C. J., Moir, A. J. G. \& Pires, E. V. (1992) Specificity of a milk clotting enzyme extracted from the thistle Cynara cardunculus $\mathrm{L}$.: action on oxidised insulin and K-cascin, Biotech. Lett. 14, 841846 .

23. Heimgartner, U., Pietrzak, M., Geertsen, R., Brodelius, P. Figueiredo, A. C. \& Pais, M. S. (1990) Purification and partial characterization of milk clotting proteinases from flowers of Cynara cardunculus L., Phytochemistry 29, 1405-1410.

24. Martin, P. (1984) Hydrolysis of the synthetic chromophoric hexapeptide Leu-Ser-Phe( $\mathrm{NO}_{2}$ )-Nle-Ala-Leu-oMe catalyzed by bovine pepsin A, Biochem. Biophys. Acta 791, 28-36.

25. Katzenellenbogen, W. M. \& Dobrys7ycka, W. M. (1959) New method for quantitative determination of serum proteins separated by paper electrophoresis, Clin. Chim. Acta 4, 515-522.

26. Laemmli, U. K. (1970) Cleavage of structural proteins during the assembly of the head of bacteriophage T4, Nature 227, 680-685.

27. Hawkc, D. \& Yuan, P. (1987) Microscale alkylation with 4-vinylpyridine, Applied Biosystem user's bulletin issue 28.

28. Green, N. M, \& Work, E. (1953) Pancreatic trypsin inhibitor: 2 , Reaction with trypsin, Biochem. J. 154, 347-352.

29. Esteves, C. L. (1995) Estudo comparativo das características bioquímicas dos coalhos de Cynara cardunculus L., Cynara scolymus L. e Cynara humilis L., MSc Thesis, University of Coimbra, Portugal

30. Veríssimo, P., Esteves, C., Faro, C. \& Pires, E. (1995) The vegetable rennct of Cynara cardunculus L. contains two proteinases with chymosin and pepsin-like specificities, Biotech. Lett. 17, 621-625.

31. Ido, E., Han, H. P., Kezdy, F. J. \& Tang, J. (1991) Kinetic studies of human inmunodeficiency virus type 1 protease and its activesite hydrogen bond mutant A28S, J. Biol. Chem. 266, 2435924366.

32. Lin, Y., Fusek, M., Lin, X., Hartsuck, J. A., Kezdy, F. J. \& Tang, J. (1992) $\mathrm{pH}$ dependence of kinetic parameters of pepsin, thizopuspepsin and their active-site hydrogen bond mutants, J. Biol. Chem. 267, 18413-18418.

33. Tokés, Z. A., Woon, W. C. \& Chambers, S. M. (1974) Digestive enzymes secreted by the carnivorous plant Nepenthes macferlanei L., Planta (Berlin) 119, 39-46.

34. Runeberg-Roos, P., Kervinen, J., Kovaleva, V., Raikhel, N. V. \& Gal, S. (1994) The aspartic proteinase of barley is a vacuolar enzyme that processes probarley lectin in vitro, Plant Physiol. $105,321 \cdot 329$.

35. Barret, A. J. (1977) Proteinases in mammalian cells and tissues, pp. 209-248, Elsevier-North Holland, New York

36. Ammerer, G., Hunter, C. P., Rothman, J. H., Saari, G. C., Valls, L. A. \& Stevens, T. H. (1986) PEP4 gene of Saccharomyces cerevisiae encodes proteinase $\mathrm{A}$, a vacuolar enzyme required for processing of vacuolar precursors, Mol. Cell Biol. 6, 2490-2499.

37. Guruprasad, K., Tormakangas, K., Kervinen, J. \& Blundell, T. (1994) Comparative modelling of barley-grain aspartic proteinase: a structural rationale for obscrved hydrolytic specificity, FEBS Lett. 352, 131-136. 